\title{
THE IMPLEMENTATION OF THE JOINT AGREEMENT IN THE FORM OF COMPENSATION FOR TERMINATION OF EMPLOYMENT THAT CONTRARY TO LABOR LAW
}

\section{PENERAPAN PERJANJIAN BERSAMA BERUPA PEMBERIAN KOMPENSASI PEMUTUSAN HUBUNGAN KERJA YANG BERTENTANGAN DENGAN UNDANG-UNDANG KETENAGAKERJAAN}

\author{
Yusuf Randi*
}

yusuf13randi@gmail.com

(Diterima pada: 01-12-2019 dan dipublikasikan pada: 01-03-2020)

\begin{abstract}
Humans as social creatures always work, either endeavored alone or work with others in meeting their needs, which then gave birth to work relationships. The working relationship in the journey does not always run harmoniously but there are often disputes that sometimes end with the termination of employment (PHK), as happened in the Supreme Court Decree No: $788 \mathrm{k} / \mathrm{Pdt}$.Sus-PHI/2018, where the company laid off workers against and provide compensation for layoffs based on collective agreements and are not guided by the provisions of layoffs in Law No. 13 concerning Manpower.The method of approach used is normative juridical, with research specifications analytical descriptive. The results showed that the joint agreement applied by the Supreme Court Judge as a legal basis in resolving cases, defects an objective requirement that is violating the halal causal conditions, because it regulates layoff compensation whose value is not under the provisions of Article 156 paragraph (1), (2), (3) and (4) the Manpower Act, thus violating the legal conditions of the agreement in Article 1320 of the Civil Code, therefore the agreement is invalid and has no legal force.
\end{abstract}

Keywords: Conpensation, Work Termination, Joint Agreement

\begin{abstract}
ABSTRAK
Manusia sebagai makhluk sosial selalu bekerja, baik diupayakan sendiri atau bekerja dengan orang lain dalam memenuhi kebutuhan hidupnya, yang kemudian melahirkan hubungan kerja. Hubungan kerja tersebut dalam perjalannya tidak selalu berjalan harmonis melainkan sering terjadi perselisihan yang terkadang berakhir dengan pemutusan hubungan kerja (PHK), seperti yang terjadi dalam Putusan Mahkamah Agung No: 788k/Pdt.Sus-PHI/2018, dimana pihak perusahaan melakukan PHK terhadap pekerja dan memberikan kompensasi PHK yang didasari pada perjanjian bersama dan tidak berpedoman pada ketentuan PHK dalam UU No 13 Tentang Ketenagakerjaan. Metode pendekatan yang digunakan bersifat yuridis normatif, dengan spesifikasi penelitian bersifat deskriptif analitis. Hasil penelitian ini menunjukan bahwa perjanjian bersama yang diterapkan oleh Hakim MA sebagai dasar hukum dalam menyelesaikan perkara, cacat syarat objektif yaitu melanggar syarat kausa yang halal, karena mengatur kompensasi PHK yang nilainnya tidak sesuai dengan ketentuan Pasal 156 ayat (1), (2), (3) dan (4) UU Ketenagakerjaan, sehingga melanggar syarat sah perjanjian dalam Pasal 1320 KUHPerdata, oleh karena itu perjanjian tersebut tidak sah dan tidak memiliki kekuatan hukum.
\end{abstract}

Kata Kunci : Kompensasi, Pemutusan Hubungan Kerja, Perjanjian Bersama

*Fakultas Hukum-Universitas Padjadjaran Bandung 


\section{A. Pendahuluan}

Sebagai makhluk sosial atau zoon politicon, manusia dalam kehidupannya selalu berusaha dan melakukan berbagai aktivitas serta interaksi dengan manusia lain dalam memenuhi kebutuhannya yang beragam. Salah satu aktivitas itu diwujudkan dalam gerakan-gerakan yang dinamakan kerja. Sebagai pekerja, manusia dapat bekerja dan melakukan pekerjaan yang diusahakan sendiri maupun bekerja pada orang lain, bekerja pada orang lain maksudnya adalah bekerja dengan bergantung pada orang lain, yang memberi perintah dan mengutusnya. ${ }^{1}$ Sehingga melahirkan hubungan yang bersifat vertikal antara pekerja dengan pemberi kerja, yang dalam perjalanannya terkadang dapat menimbulkan berbagai konflik karena adanya kedudukan dan kepentingan yang berbeda.

Sebagai negara kesatuan, Indonesia menjadikan Pancasila sebagai satusatunya ideologi negara, hal ini mengandung konsekuensi bahwa segala tatanan kehidupan di Negara Kesatuan Republik Indonesia ini harus didasarkan pada nilai-nilai yang terkandung di dalam Pancasila, termasuk di dalamnya adalah tatanan dalam hubungan industrial. ${ }^{2}$

Tujuan hubungan industrial dalam pembangunan nasional adalah untuk mewujudkan masyarakat yang adil dan makmur berdasarkan Pancasila serta ikut dalam melaksanakan ketertiban dunia yang berdasarkan perdamaian abadi, dan keadilan sosial melalui penciptaan ketenangan, ketenteraman, dan ketertiban kerja serta usaha, meningkatkan produksi, dan meningkatkan kesejahteraan pekerja juga derajatnya sesuai derajat manusia. ${ }^{3}$ Untuk mewujudkan hubungan industrial yang demikian itu, tentu diperlukan adanya

1 Zainal Asikin dkk, 2004, Dasar-Dasar Hukum Perburuhan, Jakarta: Rajagrafindo Persada, hlm. 1.

2 Indi Nuroini, "Penerapan Perjanjian Bersama Dalam Pemutusan Hubungan Kerja," Jurnal Yudisial, Vol. 8, No. 3, Desember 2015, hlm. 320.

3 Abdul Khakim, 2014, Dasar-Dasar Hukum Ketenagakerjaan Indonesia, Cet. Ke-4 Edisi Revisi, Bandung: Citra Aditya Bakti, hlm. 79. suatu kaidah-kaidah hukum yang diharapkan dapat menjadi pedoman atau pegangan dalam menjalankan hubungan industrial sesuai dengan tujuan dan yang dicita-citakan. Mengenai kaidah-kaidah hukum dalam hubungan industrial, pemerintah sebagai salah satu pihak dalam pelaksanaan hubungan industrial telah membuat peraturan perundang-undangan di bidang hubungan industrial sala adalah UU No. 13 Tahun 2003 tentang Ketenagakerjaan (selanjutnya disebut UU Ketenagakerjaan). Sebagai instrumen hukum utama di bidang ketenagakerjaan. UU Ketenagakerjaan mengatur mengenai pelaksanaan hubungan industrial sejak akan terbentuknya hubungan industrial tersebut hingga berakhirnya hubungan industrial yang telah dibangun antara pekerja/buruh dengan pengusaha.

Selain UU Ketenagakerjaan, pemerintah juga membentuk UndangUndang No. 2 Tahun 2004 tentang Penyelesaian Perselisihan Hubungan Industrial (selanjutnya disebut UUPPHI). Undang-undang ini berisi mekanisme yang dapat dipilih oleh pengusaha dan pekerja dalam menyelesaikan perselisihan hubungan industrial yang terjadi. Sebab, setiap interaksi yang terjadi dalam hubungan kerja dalam perjalanannya tidak selalu berjalan dengan harmonis, melainkan seringkali pula terjadi berbagai gejolak dan ketegangan. Ketegangan antara pekerja dan pengusaha sering memicu terjadinya perselisihan hubungan industrial, ${ }^{4}$ yang terkadang berakhir dengan PHK yang dilakukan oleh pengusaha terhadap pekerja.

Salah satu fungsi yang terpenting peraturan perundang-undangan sebagai suatu produk hukum adalah tercapainya keteraturan dan ketertiban dalam kehidupan manusia di masyarakat. ${ }^{5}$ Dibentuknya kedua intsrumen dibidang

4 Ujang Charda S., "Model Penyelesaian Perselisihan Hubungan Industrial Dalam Hukum Ketenagakerjaan Setelah Lahirnya Undang-Undang Nomor 2 Tahun 2004," Jurnal Wawasan Yuridika, Vol. 1, No. 1, Maret 2017, hlm. 3.

Mochtar Kusumaatmadja dan Arief Sidharta, 2000, Pengantar Ilmu Hukum : Suatu Pengenalan Pertama Ruang Lingkup Berlakunya Ilmu Hukum, Buku I, Bandung: Alumni, hlm. 50. 
hubungan industrial tersebut, pada hakikatnya adalah norma yang digunakan untuk menjaga ketertiban, keteraturan dan intrumen untuk menyelesaikan masalahmasalah yang terjadi.

Perselisihan hubungan industrial ada yang bisa diselesaikan melalui mekanisme diluar pengadilan yaitu secara bipartit, mediasi, konsiliasi, arbitrasi maupun penyelesaian melalui mekanisme pengadilan. ${ }^{6}$ Penyelesaian perselisihan melalui mekanisme pengadilan memiliki peran penting dalam menciptakan hubungan industrial yang berkemanusiaan, berkeadilan sosial dan berkepastian hukum, khususnya Pengadilan Hubungan Industrial sebagai tempat mencari keadilan. Pengadilan Hubungan Industrial (PHI) merupakan pengadilan khusus yang menangani, memeriksa, mengadili, dan memutus perselisihan hubungan industrial yang berada pada lingkungan peradilan umum, ${ }^{7}$ dan berpuncak pada Mahkamah Agung. Peradilan umum dimungkinkan membentuk pengadilan khusus berdasarkan undang-undang, sebagaimana tertuang dalam Pasal 27 Undang-Undang No. 48 Tahun 2009 Tentang Kekuasaan Kehakiman (selanjutnya disebut UU Kekuasaan Kehakiman). ${ }^{8}$

Mahkamah Agung sebagai puncak semua peradilan dan sebagai pengadilan tertinggi untuk semua lingkungan peradilan, diharapkan setiap putusan yang dihasilkan oleh para Hakim Agung dapat mengubah atau menjadi sarana perubah (agent of change) keadaan.

Sebagai lembaga peradilan, Mahkamah Agung diharapkan menjadi sebuah badan yang berwibawa, independen, tidak berpihak, dan mampu menegakkan peraturan perundangundangan dengan baik. Hal ini mengingat bahwa dalam badan peradilan, hakim melalui segala kewenangan yang dimilikinya memiliki peran penting

6 Sri Subiandini Gultom, 2008, Aspek Hukum Hubungan Industrial, Jakarta: Inti Prima Promosindo, hlm. 61.

${ }^{7}$ Ugo dan Pujiyo, 2012, Hukum Acara Penyelesaian Perselisihan Hubungan Industrial, (Tata Cara dan Proses Penyelesaian Sengketa Perburuhan), Cet. Ke-2, Jakarta: Sinar Grafika, hlm. 91.

\footnotetext{
${ }^{8}$ Ibid.
}

terutama dalam memutus dan mengadili setiap perkara yang dihadapi, melalui putusannya pula akan dapat diketahui kualitas dan profesionalitas dari seorang hakim dalam melaksanakan tugasnnya.

Pada putusan Mahkamah Agung Nomor: 788k/Pdt.Sus-PHI/2018 yang mengadili perkara di tingkat kasasi antara PT Sentra Info Bisnis Konsutama dan PT Media Komunitas Serpong (selaku Para Pemohon) melawan Ramzanullah yang merupakan pekerja (selaku Termohon).

Perkara tersebut berawal dari adanya perselisihan hubungan kerja antara pekerja (Ramzanullah) dengan pihak perusahaan (PT Media Komunitas Serpong dan PT Sentra Info Bisnis Konsultama), yang kemudian berujung pada pemutusan hubungan kerja (PHK) secara sepihak yang dilakukan oleh PT Sentra Info Bisnis Konsultama, dimana kedua perusahaan tersebut diketahui adalah perusahaan yang berada dalam satu kelompok usaha yang sama yaitu Info Gading Group dengan Direktur Utama yaitu Sukardi Darmawan.

Sebagai pihak yang melakukan PHK, PT Sentra Info Bisnis Konsultama dan PT Media Komunitas Serpong diketahui memberikan kompensasi PHK yang terdiri dari uang pesangon dan hakhak lainnya yang jumlahnya tidak didasari pada ketentuan UU Ketenagakerjaan, melainkan dari ketentuan perjanjian bersama (PB) yang sebelumnya telah disepakati oleh kedua belah pihak.

Dalam menyelesaikan perselisihan PHK ini, pekerja dan PT Sentra Info Bisnis Konsultama telah melakukan perundingan secara bipartit dan tripartit yaitu mediasi melalui Suku Dinas Ketenagakerjaan Jakarta Utara. Akan tetapi upaya mediasi tersebut tidak mencapai kesepakatan, sehingga membuat pekerja menempuh tindakan hukum selanjutnya yaitu mengajukan gugatan ke Pengadilan Hubungan Industrial pada Pengadilan Negeri Jakarta Pusat.

Dalam putusannya, majelis Hakim
PHI memenangkan Pekerja dan menyatakan putus hubungan kerja antara Penggugat dengan PT sentra Info Bisnis Konsultama sejak tanggal 2 Juli 2016, serta menghukum perusahaan untuk membayar sisa kompensasi PHK kepada 
pekerja berupa uang pesangon, uang penghargaan masa kerja dan uang penggantian hak yang seluruhnya sebesar Rp.31.169.500,00 (tiga puluh satu juta seratus enam puluh sembilan ribu lima ratus rupiah).

Terhadap putusan PHI tersebut, ternyata tidak memberikan rasa keadilan bagi pihak perusahaan dan mengajukan upaya hukum kasasi ke Mahkamah Agung. Dalam amar putusannya, majelis hakim mengabulkan permohonan kasasi yang diajukan pihak perusahaan dan membatalkan Putusan Pengadilan Hubungan Industrial pada Pengadilan Negeri Jakarta Pusat, karena menilai judex facti tidak mempertimbangkan adanya bukti berupa perjanjian bersama (PB) antara pekerja dengan PT Sentra Info Bisnis Konsultama, yang menyepakati PB yang sebelumnya dibuat antara pekerja dengan PT Media Komunitas Serpong mengenai uang kompensasi PHK dan telah dibayar

Berdasarkan pertimbangan hukum tersebut majelis hakim kasasi dalam memutuskan perkara telah menggunakan kesepakatan bersama sebagai dasar pertimbangan hukum yang utama dalam menyelesaikan perkara antara Para Pemohon dengan pekerja.

Sesuai dengan judul dan latar belakang masalah di atas, maka dapat dirumuskan permasalahan sebagai berikut, apakah perjanjian bersama yang dibuat antara pihak perusahaan dan pekerja di tingkat bipartit mengenai kompensasi PHK yang nilainya bertentangan dengan UU Ketenagakerjaan dapat dijadikan sebagai dasar hukum dalam memutus perkara perselisihan hubungan industrial di tingkat pengadilan? apakah pertimbangan hukum Mahkamah Agung dalam menyelesaikan perselisihan hubungan industrial antara pihak perusahaan dengan pekerja sudah sesuai dengan ketentuan UU Ketenagakerjaan?

Adapun penelitian ini menggunakan pendekatan yuridis normatif yaitu meneliti tentang penerapan perjanjian bersama (PB) dalam pemberian kompensasi PHK. Oleh karena itu, kasus yang diteliti lebih melihat dari legal-formilnya. Disamping itu, Pendekatan yang dilakukan berdasarkan pada bahan hukum utama yaitu peraturan perundang- undangan yang berhubungan dengan penelitian ini, yang disertai dengan menelaah berbagai teori-teori, konsep-konsep, asas-asas hukum, dimana penelitian seperti ini dikenal dengan pendekatan kepustakaan.

B. Analisis Terhadap Penerapan Perjanjian Bersama Sebagai Dasar Hukum Dalam Memutus Perkara Perselisihan Hubungan Industrial di Tingkat Pengadilan

Bagaimanapun harmonisnya hubungan antara pengusaha dengan pekerja pasti timbul perselisihanperselisihan diantara mereka yang diakibatkan karena banyaknya kepentingan yang saling bertentangan. Termasuk perselisihan yang terjadi antara pekerja dengan PT Media Komunitas Serpong dan PT Sentra Info Bisnis Konsultama, yang berujung pada pemutusan hubungan kerja (PHK) secara sepihak yang dilakukan oleh PT Sentra Info Bisnis Konsultama pada tanggal 2 Juli 2016.

Sebagai pihak yang melakukan PHK, PT Sentra Info Bisnis Konsultama diketahui memberikan kompensasi PHK yang terdiri dari uang pesangon dan hak-hak lainnya yang jumlahnya tidak didasari pada ketentuan UU Ketenagakerjaan, melainkan didasari pada ketentuan perjanjian bersama (PB) antara pekerja dengan PT Sentra Info Bisnis Konsultama, yang menyepakati PB sebelumnya antara pekerja dengan PT Media Komunitas Serpong.

Pasal 1 angka 1 UUPPHI mendefenisikan perselisihan hubungan industrial sebagai perbedaan pendapat yang mengakibatkan pertentangan antara pengusaha atau gabungan pengusaha dengan pekerja/buruh atau serikat pekerja/serikat buruh karena adanya perselisihan mengenai hak, perselisihan kepentingan, perselisihan pemutusan hubungan kerja dan perselisihan antar serikat pekerja/serikat buruh dalam satu 
perusahaan. Dari pengertian tersebut, maka dapat diketahui bahwa ada 4 (empat) jenis perselisihan hubungan kerja yaitu perselisihan hak, perselisihan kepentingan, perselisihan pemutusan hubungan kerja dan perselisihan antar serikat pekerja/serikat buruh dalam satu perusahaan. $^{9}$

Menurut UUPPHI, terhadap perselisihan hubungan industrial tersebut dapat diselesaikan melalui 2 (dua) tahap/prosedur yaitu penyelesaian melalui mekanisme diluar pengadilan yaitu secara bipartit, mediasi, konsiliasi, arbitrasi atau penyelesaian melalui mekanisme pengadilan.

Pasal 1 angka 10 UUPPHI mendefenisikan perundingan bipartit sebagai perundingan antara pekerja/buruh atau serikat pekerja/serikat buruh dengan pengusaha untuk menyelesaikan perselisihan hubungan industrial. Selanjutnya dalam Pasal 3 ayat (1) UUPPHI menentukan bahwa setiap perselisihan hubungan industrial yang terjadi wajib diupayakan penyelesaiannnya terlebih dahulu melalui perundingan bipartit secara musyawarah untuk mencapai mufakat. Dari ketentuan tersebut, dapat diketahui bahwa undang-undang telah menentukan secara tegas bahwa setiap perselishan yang terjadi (perselisihan hak, perselisihan kepentingan, perselisihan PHK, dan perselisihan antar serikat pekerja) antara pekerja dengan pengusaha wajib hukumnya untuk diselesaikan sendiri oleh pihakpihak yang berselisih secara bipartit sebelum menempuh mekanisme penyelesaian perselisihan yang lain. ${ }^{10}$

Sementara itu, apabila pada proses bipartit tercapai suatu kesepakatan yang menjadikan perdamaian bagi kedua belah pihak, maka kesepakatan-kesepakatan tersebut dituangkan dalam sebuah perjanjian bersama (PB) yang kemudian ditandatangani oleh kedua belah pihak dan didaftarkan ke Pengadilan Hubungan Industrial pada PN di wilayah dimana para pihak mengadakan perjanjian bersama. Karena telah menjadi kesepakatan kedua belah pihak, maka perjanjian tersebut bersifat mengikat bagi kedua belah pihak sesuai dengan asas pacta sunt servanda sehingga wajib dilaksanakan. ${ }^{11}$

Pada perkara PHK yang telah diputus oleh Mahkamah Agung (MA) dengan Putusan Nomor788K/Pdt.Sus$\mathrm{PHI} / 2018$. Berdasarkan putusan tingkat pertama yaitu putusan PHI Jakarta Pusat Nomor 65/Pdt.SusPHI/2017/PN.JKT.PST, diketahui bahwa pekerja awalnya adalah pekerja dari PT Media Komunitas Serpong sejak tanggal 3 Agustus 2007, namun pada tanggal 2 Juli 2015 PT Media Komunitas Serpong menawarkan untuk dilakukannya pemutihan kontrak kerja. Perusahaan menawarkan kepada pekerja berupa pemberian kompensasi sebesar Rp. 9.000.000,00 (sembilan juta rupiah), tetap mendapatkan bayaran tunjangan hari raya (THR) dan tawaran untuk bekerja di PT Sentra Info Bisnis Konsultama pada jabatan yang sama dengan masa kerja yang tetap terhitung sejak pekerja bekerja di PT Media Komunitas Serpong. Kedua perusahaan tersebut diketahui merupakan dua perusahaan yang tergabung dalam satu kelompok usaha yang sama yaitu Info Gading Group dengan Direktur utama Sukardi Darmawan.

Pekerja kemudian menerima tawaran tersebut, dan terjadi kesepakatan secara bipartit antara kedua belah pihak pada tanggal 2 Juli 2015, yang kemudian dituangkan dalam perjanjian bersama (PB) dan telah didaftarkan di PHI pada

\footnotetext{
${ }^{9}$ Ugo dan Pujiyo, Op.Cit., hlm. 25
}

${ }^{10}$ Ibid., hlm. 54. 
Pengadilan Negeri Serang dengan akta pendaftaran PB No: 73/BIP/PHI/2016/PN.SRG, sehingga sesuai dengan ketentuan Pasal 7 ayat (1) UUPPHI yang menyebutkan dalam hal musyawarah sebagaimana dimaksud dalam Pasal 3 dapat mencapai kesepakatan penyelesaian, maka dibuat perjanjian bersama yang ditandatangani oleh para pihak, selanjutnya Pasal 7 ayat (3) menyebutkan bahwa terhadap perjanjian bersama sebagaimana dimaksud dalam ayat (1) wajib didaftarkan oleh para pihak yang melakukan perjanjian pada Pengadilan Hubungan Industrial pada Pengadilan Negeri di wilayah para pihak mengadakan Perjanjian Bersama.

Berdasarkan perjanjian bersama (PB) tersebut, pekerja kemudian mulai bekerja di PT Sentra Info Bisnis Konsultama pada tanggal 3 Juli 2015, namun, pada 2 Juli 2016 perusahaan melakukan pemutusan hubungan kerja (PHK) secara sepihak, dengan alasan karena telah berakhirnya jangka waktu perjanjian kerja. Sehingga hakhak PHK pekerja seperti uang pesangon tidak menjadi kewajiban PT Sentra Info Bisnis Konsultama, melainkan kewajiban PT Media Komunitas Serpong dan telah dibayar sesuai ketentuan perjanjian bersama (PB).

$\begin{array}{crrr}\text { Pasal } 1 & \text { angka } & 25 & \text { UU } \\ \text { Ketenagakerjaan } & \text { PHK } & \text { diartikan }\end{array}$ sebagai bentuk pengakhiran hubungan kerja karena suatu hal tertentu yang mengakibatkan berakhirnya hak dan kewajiban antara pekerja dan pengusaha. Ketika terjadi PHK, UU Ketenagakerjaan telah mengatur ketentuan-ketentuan hukum mengenai hak-hak pekerja/buruh yang mengalami PHK, di antaranya yaitu Pasal 156 ayat (1) yang menyebutkan bahwa dalam hal terjadi pemutusan hubungan kerja (PHK), pengusaha diwajibkan membayar uang pesangon dan atau uang penghargaan masa kerja dan uang penggantian hak yang seharusnya diterima.

Berdasarkan ketentuan tersebut, dalam pertimbangan Majelis Hakim PHI, PHK yang dilakukan oleh PT Sentra Info Bisnis Konsultama karena alasan telah berakhirnya waktu perjanjian kerja dan pihak perusahaan tidak lagi menghendaki hubungan kerja tersebut, sedangkan disisi lain pekerja tidak pula keberatan di PHK asalkan perusahaan membayar seluruh kewajibannya sesuai ketentuan UU Ketenagakerjaan. Dengan demikian Majelis Hakim PHI pada PN Jakarta Pusat kemudian menyataan putus hubungan kerja (PHK) antara pekerja dengan PT Sentra Info Bisnis Konsultama pada tanggal 2 Juli 2016, dan menghukum perusahaan untuk membayar uang kompensasi PHK kepada pekerja berupa uang pesangon 2 (dua) kali ketentuan Pasal 156 ayat (2), uang penghargaan masa kerja 1 (satu) kali ketentuan Pasal 156 ayat (3), dan uang penggantian hak sesuai ketentuan Pasal 156 ayat (4).

Sementara itu, mengenai perhitungan uang kompensasi PHK yang menjadi hak pekerja sebagaimana ketentuan Pasal 156 ayat (2), (3), dan (4) tersebut adalah:

\section{Uang Pesangon}

Merupakan pembayaran dalam bentuk uang dari pengusaha kepada buruh/pekerja sebagai akibat adanya PHK yang jumlahnya disesuaikan dengan masa kerja buruh/pekerja yang bersangkutan. ${ }^{12}$

\section{Uang Penghargaan Masa Kerja Merupakan uang penghargaan yang diberikan pengusaha kepada pekerja yang dikaitkan dengan lamanya masa kerja. ${ }^{13}$}

12 Lalu Husni, 2014, Pengantar Hukum Ketenagakerjaan, Edisi Revisi, Jakarta: Rajagrafindo Persada, hlm. 186.

${ }^{13}$ Abdul Khakim, Op.Cit., hlm. 203. 
3. Uang Penggantian Hak

Merupakan pembayaran berupa uang dari pengusaha kepada pekerja sebagai penggantian istirahat tahunan, istirahat panjang, biaya perjalanan ke tempat di mana pekerja diterima bekerja, fasilitas pengobatan, fasilitas perumahan, dan lainnya sebagai akibat PHK. ${ }^{14}$

Berdasarkan ketentuan di atas, mengingat bahwa antara pekerja dan PT Media Komunitas Serpong sebelumnya terdapat Perjanjian Bersama (PB), yang menyepakati adanya keberlanjutan hubungan kerja pekerja dari PT Media Komunitas Serpong ke PT Sentra Info Bisnis Konsultama dan keberlanjutan hubungan kerja tersebut diperkuat dengan adanya bukti surat himbauan cuti tanggal 27 Mei 2016 yang dikeluarkan oleh PT Sentra Info Bisnis Konsultama, yang justru mengakui tanggal masuk kerja pekerja pada 3 Agustus 2007 dan pengakuan tersebut oleh Majelis Hakim PHI Jakarta Pusat dianggap sebagai bukti yang sempurna serta telah memenuhi ketentuan Pasal 174 dan 176 HIR jo. Pasal 1865 KUHPerdata yang menilai pengakuan tersebut sebagai bukti yang sempurna. Sehingga masa kerja pekerja tetap harus dihitung sejak pekerja bekerja pada PT Media Komunitas Serpong yaitu 3 Agustus 2007.

Mengingat upah pokok pekerja sebesar Rp.3.493.000,00/bulan. Maka besaran kompensasi PHK yang seharusnya diterima oleh pekerja dari PT Sentra Info Bisnis Konsultama dan PT Media Komunitas Serpong dengan masa kerja 8 tahun 11 bulan menurut Peneliti sebagai berikut:

Uang Pesangon:

2 × 9 x Rp. 3.493.000,00 =Rp. $62.874 .000,00$

${ }^{14}$ Ibid.
Uang Penghargaan masa kerja:

1 x 3 x Rp. 3.493.000,00 =Rp. $10.479 .000,00$

Uang Penggantian Hak:

$15 \% \quad \mathrm{X} \quad 73.353 .000,00=$
Rp.11.002.950,00

Total $=$ Rp.84.355.950,00

Berdasarkan ketentuan hukum mengenai PHK, baik mengenai sebab PHK maupun jumlah uang pesangon yang berhak diterima pekerja dalam kasus ini, seolah-olah tidak dipertimbangkan sama sekali oleh Majelis Hakim MA yang memeriksa perkara nomor: 788K/Pdt.SusPHI/2018 tersebut, hal ini terlihat dari pertimbangan hukum MA yang menilai bahwa judex facti tidak mempertimbangkan bukti berupa perjanjian bersama (PB) antara pekerja dengan PT Sentra Info Bisnis Konsultama, yang menyepakati PB sebelumnya antara pekerja dengan PT Media Komunitas Serpong untuk membayar kompensasi sebesar Rp.9.000.000,00 (sembilan juta rupiah). Apabila bukti-bukti tersebut dipertimbangkan maka diperoleh fakta hukum telah terjadi perjanjian bersama dan telah dibayar oleh karenanya sesuai ketentuan Pasal 7 UUPPHI, perjanjian bersama tersebut sama dengan putusan pengadilan.

Pertimbangan hukum tersebut jelas menunjukan bahwa Majelis Hakim MA hanya menjadikan perjanjian bersama (PB) tanggal 3 Juli 2015 sebagai satu-satunya dasar hukum dalam menyelesaikan perkara perselisihan antara pihak perusahaan dan pekerja. Majelis Hakim MA tampaknya juga kurang cermat dalam menilai alat bukti surat perjanjian bersama (PB) yang diajukan dalam perkara tersebut. Seharusnya Majelis Hakim MA menilai apakah PB tersebut mengandung cacat hukum atau tidak. 
Mengingat bahwa UU Ketenagakerjaan sebagai aturan pokok dibidang ketenagakerjaan (lex specialis), begitu juga UUPPHI tidak mengatur secara rinci, maka mengenai ketentuan perjanjian bersama (PB), berlaku ketentuan umum perjanjian yang terdapat dalam buku III KUHPerdata sebagai lex generalis.

Perjanjian bersama (PB) yang dibuat antara pihak perusahaan dan pekerja didasari pada asas kebebasan berkontrak sebagai asas umum perjanjian. Asas kebebasan berkontrak ini memberikan jaminan kebebasan kepada seseorang untuk secara bebas dalam beberapa hal yang berkaitan dengan perjanjian yaitu bebas menentukan apakah akan melakukan perjanjian atau tidak, bebas menentukan dengan siapa melakukan perjanjian, bebas menentukan isi atau klausul, bentuk perjanjian dan lainnya, ${ }^{15}$ sepanjang tidak bertentangan dengan peraturan perundang-undangan, ketertiban umum, dan kepatutan dalam masyarakat.

PB yang telah disepakati (konsensual) kemudian mengikat bagi para pihak yang membuatnya guna memenuhi perjanjian tersebut. Ketentuan ini dikenal sebagai asas kekuatan mengikat (pacta sunt servanda), yang mengandung arti bahwa setiap perjanjian yang dibuat oleh para pihak maka para pihak akan terikat untuk memenuhi perjanjian karena mengandung janji-janji yang harus dipenuhi dan janji tersebut mengikat para pihak sebagaimana mengikatnya undang-undang. ${ }^{16}$ Asas ini terkandung dalam Pasal 1338 ayat (1) KUHPerdata yang menentukan bahwa semua perjanjian yang dibuat secara sah berlaku sebagai undangundang bagi mereka yang

15 Ahmadi Miru, 2016, Hukum Kontrak \& Perancangan Kontrak , Jakarta: Rajagrafindo Persada, hlm. 4.

${ }^{16}$ Ibid., hlm. 5 membuatnya. ${ }^{17}$ Asas kekuatan mengikat hanya akan berlaku apabila perjanjian yang dibuat oleh para pihak terlebih dahulu memenuhi syarat sahnya perjanjian sebagaimana tercantum dalam Pasal 1320 KUHPerdata yang menyebutkan bahwa setiap perjanjian yang dibuat akan dinyatakan sah apabila memenuhi empat syarat sahnya perjanjian sebagai berikut:

1. Kesepakatan para pihak untuk mengikatkan diri;

2. Kecakapan para pihak untuk membuat perjanjian;

3. Suatu hal tertentu dan;

4. Suatu sebab yang halal.

Berdasarkan empat syarat sah perjanjian dalam Pasal 1320 KUHPerdata tersebut, syarat pertama dan kedua disebut sebagai syarat subjektif, karena berkaitan dengan subjek perjanjian, yaitu kesepakatan dan cakap membuat perjanjian. Cacat mengenai syarat subjektif, maka perjanjian tersebut dapat dibatalkan (vernietigbaar) dan selama pembatalannya belum diajukan, perjanjian itu tetap sah. ${ }^{18}$ Sedangkan syarat ketiga dan keempat adalah syarat objektif, yaitu mengenai objek perjanjian dan kausa, yaitu tujuan mengenai perjanjian. Perjanjian yang cacat mengenai syarat objektif, maka perjanjian tersebut batal demi hukum (van rechtswegenietig, null and void $).{ }^{19}$

Berdasarkan ketentuan di atas, dapat disimpulkan bahwa perjanjian bersama (PB) yang digunakan sebagai dasar hukum oleh Mahkamah Agung dalam menyelesaikan perkara antara pihak perusahaan dengan pekerja jelas

\footnotetext{
17 Ibid.

18 Mariam Darus Badrulzaman, 2015,
} Hukum Perikatan Dalam KUH Perdata Buku Ketiga (Yurisprudensi, Doktrin, Serta Penjelasan), Bandung: Citra Aditya Bakti, hlm. 108.

${ }^{19}$ Ibid. 
melanggar syarat sah perjanjian yaitu mengenai syarat kausa atau sebab yang halal dalam Pasal 1320 KUHPerdata, karena perjanjian bersama (PB) tersebut mengatur pemberian kompensasi PHK yaitu uang pesangon sebesar Rp.9.000.000,00 (sembilan juta rupiah). Jumlah tersebut jelas lebih rendah dan tidak sesuai dibandingkan dengan nominal uang pesangon yang seharusnya diperoleh pekerja yaitu Rp.62.874.000,00, (enam puluh dua juta delapan ratus tujuh puluh empat ribu rupiah) yang didasari pada ketentuan Pasal 156 ayat (2), UU Ketenagakerjaan.

Sementara itu, berdasarkan ketentuan Pasal 156 ayat (1) dan Pasal 156 ayat (2), (3) dan (4), kompensasi PHK yang seharusnya diterima oleh pekerja dari pihak perusahaan terdiri atas uang pesangon, uang penghargaan masa kerja dan uang penggantian hak, yang jumlahnya sebesar Rp.84.355.950,00 (delapan puluh empat juta tiga ratus lima puluh lima ribu sembilan ratus lima puluh rupiah), dan tidak hanya sebatas uang pesangon saja sebagaimana ketentuan perjanjian bersama (PB).

Kausa atau sebab adalah tujuan, isi, dan maksud yang dikehendaki bersama oleh para pihak untuk mengadakan perjanjian yang melahirkan hubungan hukum. ${ }^{20}$ Perjanjian tanpa adanya kausa yang halal mengakibatkan perjanjian tersebut batal demi hukum dan tidak sah. Pasal 1337 KUHPerdata menyebutkan bahwa kausa yang dilarang ialah kausa yang dilarang oleh undang-undang, berlawanan dengan kesusilaan baik atau ketertiban umum. ${ }^{21}$

Terkait dengan suatu perjanjian yang mengandung kausa atau sebab yang bertentangan dengan undangundang, terdapat asas lex dura sed tamen scripta atau lex dura sed ita

\footnotetext{
${ }^{20}$ Ibid., hlm. 120.

${ }^{21}$ Ibid., hlm. 121.
}

scripta yang artinya bahwa undangundang bersifat keras (memaksa) ${ }^{22}$, sehingga tidak dapat diganggu gugat dan telah tertulis. Oleh karena itu suatu perjanjian yang mengandung kausa bertentangan dengan undang-undang secara otomatis batal demi hukum (van rechtswegenietig, null and void), artinya perjanjian tersebut tidak memiliki kekuatan hukum yang mengikat para pihak. ${ }^{23}$ Hal ini sejalan dengan ketentuan Pasal 1335 KUHPerdata yang menyebutkan bahwa suatu persetujuan tanpa sebab, atau dibuat berdasarkan suatu sebab yang palsu atau yang terlarang, tidaklah mempunyai kekuatan.

Perjanjian yang batal demi hukum, kebatalannya bersifat absolut (absoluut nietig) ${ }^{24}$ oleh karenannya perjanjian yang dibuat oleh para pihak sejak semula dianggap tidak ada (nonexistence) dan tidak mempunyai akibat hukum. ${ }^{25}$ Sehingga para pihak tidak memiliki dasar untuk saling menuntut di muka sidang pengadilan.

Sementara itu, sejalan dengan hal di atas, Muhammad Hafidz selaku Praktisi Hukum Ketenagakerjaan memandang keliru Putusan MA Nomor 788K/Pdt.Sus-PHI/2018 tersebut. Menurutnya, setiap perjanjian yang isinya lebih rendah dari undangundang, maka seharusnya dianggap batal demi hukum. Apabila dibolehkan adanya perjanjian yang bertentangan dengan undang-undang, maka hukum di negara ini bisa rusak dan memberikan ketidak pastian hukum dan rasa ketidakadilan bagi pencari keadilan. ${ }^{26}$

22 Dudu Duswara Machmudin, 2010, Pengantar Ilmu Hukum (Sebuah Sketsa), Bandung: Refika Aditama, hlm. 27.

${ }^{23}$ Indi Nuroini, Op.Cit., hlm. 330.

24 Mariam Darus Badrulzaman, Op.Cit., hlm. 122

25 Ibid.

${ }^{26}$ https://buruh-online.com/2019/01/madinilai-keliru-persamakan-perjanjian-bersama-sepertiputusan-pengadilan.htm. Diakses pada 5 Desember 2019, pukul 16:43 WIB. 
Lebih lanjut, Muhammad Hafidz dalam pendapatnya mengatakan meskipun perjanjian bersama (PB) tersebut didasari asas kebebasan berkontrak, tetapi bukan berarti asas tersebut membolehkan para pihak untuk memperjanjikan hal yang melanggar undang-undang. Hafidz juga menegaskan, pengadilan boleh menetapkan sesuatu yang tidak diatur oleh undang-undang. Sedangkan mengenai pesangon jelas sudah diatur secara tegas dalam

UU Ketenagakerjaan. Sehingga tidak boleh ada kesepakatan atau perjanjian yang isinya membolehkan nilai pesangon dibawah besaran yang sudah ditetapkan undang-undang.",27

\section{Analisis Terhadap Pertimbangan Hukum Mahkamah Agung Dalam Menyelesaikan Perselisihan Hubungan Industrial Antara Pihak Perusahaan dengan Pekerja Ditinjau Dari Ketentuan Undang- Undang Ketenagakerjaan}

Suatu proses peradilan berakhir dengan putusan akhir atau vonis. Dalam putusan itu hakim menyatakan pendapat tentang apa yang telah dipertimbangkan dalam putusannya.

Pertimbangan hakim merupakan salah satu aspek terpenting dalam menentukan terwujudnya nilai dari suatu putusan hakim yang mengandung keadilan (ex aequo et bono) dan mengandung kepastian hukum, di samping itu juga mengandung manfaat bagi para pihak yang bersangkutan sehingga pertimbangan hakim ini harus disikapi dengan teliti, baik, dan cermat.

Mahkamah Agung (MA) sebagai badan tertinggi pelaksana kekuasaan kehakiman yang membawahi empat badan peradilan dibawahnya telah menentukan bahwa putusan hakim harus mempertimbangkan segala aspek

${ }^{27}$ Ibid. yang bersifat yuridis, filosofis, dan sosiologis. ${ }^{28}$ Namun, aspek yuridis adalah aspek pertama dan utama dengan berpatokan pada undangundang yang berlaku. Hakim sebagai pelaksana undang-undang harus memahami undang-undang dengan mencari undang-undang yang berkaitan dengan perkara yang sedang dihadapi. $^{29}$

Keadilan hukum adalah keadilan berdasarkan hukum positif dan peraturan perundang-undangan. Dalam arti hakim hanya memutus perkara hanya berdasarkan hukum positif dan peraturan perundang-undangan. Dengan kata lain hakim adalah sebagai corong ataupun mulut undangundang. ${ }^{30}$

Dalam perkara perselisihan PHK yang telah diputus dengan putusan Mahkamah Agung Nomor: 788K/Pdt.Sus-PHI/2018. Majelis hakim kasasi menimbang bahwa judex facti tidak mempertimbangkan adanya bukti berupa perjanjian kerja waktu tertentu (PKWT) antara pekerja dengan PT Media Komunitas Serpong yang berakhir tanggal 2 Juli 2016, perusahaan dapat pula membuktikan pekerjaan yang dikerjakan oleh Pekerja berkaitan dengan kontrak pemasangan iklan sehingga perjanjian kerja waktu tertentu memenuhi ketentuan Pasal 59 UU Ketenagakerjaan.

Menurut Peneliti, pertimbangan hukum majelis hakim kasasi tersebut keliru serta tidak cermat dalam memahami hubungan kerja yang didasari pada PKWT antara pihak perusahaan dengan pekerja.

28 Mahkamah Agung RI, 2006, Pedoman Perilaku Hakim (Code Of Conduct), Kode Etik Hakim dan Makalah berkaitan, Jakarta: Pusdiklat MA RI, hlm. 2 .

29 L. Hendi Permana, “Analisis Pertimbangan Hukum Hakim Dalam Penjatuhan Pidana di Bawah Minimum Terhadap Pelaku Tindak Pidana Kesusilaan", Bandar Lampung: Fakultas Hukum Universitas Lampung, 2016, hlm. 6.

30 Ibid., hlm. 7. 
Perjanjian kerja waktu tertentu (PKWT) yang berakhir pada tanggal 2 Juli 2016 seharusnya adalah antara pekerja dengan PT Sentra Info Bisnis Konsultama dan bukan antara pekerja dengan PT Media Komunitas Serpong.

Pasal 1 angka 15 UU Ketenagakerjaan menjelaskan bahwa hubungan kerja adalah hubungan antara pengusaha dengan pekerja/buruh berdasarkan perjanjian kerja, yang mempunyai unsur pekerjaan, upah, dan perintah. Lebih lanjut Pasal 50 UU Ketenagakerjaan secara tegas juga menjelaskan bahwa hubungan kerja terjadi karena adanya perjanjian kerja antara pengusaha dan pekerja/buruh.

Mengenai ketentuan di atas, dapat dijelaskan bahwa hubungan kerja tidak dapat dipisahkan dari perjanjian kerja. Hubungan kerja sebagai bentuk hubungan hukum lahir atau tercipta setelah adanya perjanjian kerja antara pekerja dengan pengusaha. ${ }^{31}$ Hubungan kerja tersebut kemudian melahirkan hak dan kewajiban yang harus dipenuhi oleh masing-masing pihak (pengusaha dan pekerja/buruh).

Ditinjau dari jangka waktu, perjanjian kerja yang dibuat oleh perusahaan dengan pekerja dapat dibagi menjadi 2 (dua) jenis yaitu perjanjian kerja waktu tertentu (PKWT) dan perjanjian kerja tidak waktu tertentu (PKWT). Menurut Sedjun H. Manulang, perjanjian kerja waktu tertentu (PKWT) diartikan sebagai perjanjian kerja yang jangka waktu berlakunya ditentukan dalam perjanjian tersebut. ${ }^{32}$

Berdasarkan ketentuan tersebut, bila dikaitkan dengan kasus, dapat diketahui bahwa hubungan kerja yang

31 Lalu Husni, 2003, Hukum Ketenagakerjaan Indonesia, Edisi Revisi, Cet. Ke-4, Jakarta: Rajagrafindo, hlm. 53.

32 Sedjun H. Manulang, 2001, Pokok-Pokok Hukum Ketenagakerjaan di Indonesia, Jakarta: Rineka Cipta, hlm. 69. terjalin antara pekerja dengan PT Sentra Info Bisnis Konsultama didasari pada hubungan kerja PKWT No: 076/SPK/SIBK/VII/2016 tertanggal 3 Juli 2015 sampai dengan 2 Januari 2016 dengan durasi kontrak 6 bulan. Setelah durasi kontrak habis, para pihak sepakat memperpanjang kontrak kerja selama 6 bulan kedepan dengan kontrak nomor: 003/SPK/SIBK/I/2016 yang terhitung sejak 3 Januari 2016 sampai berakhir pada 2 Juli 2016.

Dalam jawabannya, PT Sentra Info Bisnis Konsultama menyatakan bahwa PKWT yang dibuat dengan pekerja sama sekali tidak melanggar ketentuan dalam UU Ketenagakerjaan baik mengenai upah maupun mengenai ketentuan PKWT, yaitu tidak mensyaratkan adanya masa percobaan sehingga sesuai dengan ketentuan Pasal 58 ayat (1) UU Ketenagakerjaan yang menyebutkan bahwa perjanjian kerja untuk waktu tertentu (PKWT) tidak dapat mensyaratkan adanya masa percobaan kerja.

PKWT yang dibuat juga sesuai dengan jenis pekerjaan yang dilakukan yaitu berupa kontrak pemasangan iklan antara PT Sentra Info Bisnis Konsultama dengan klien, dimana isi pekerjaan yang dilakukan Penggugat didasari atas order serta jangka waktu penyelesaiannya tidak terlalu lama, sehingga sesuai dengan ketentuan Pasal 59 UU Ketenagakerjaan yang menyebutkan bahwa PKWT hanya dapat dibuat untuk pekerjaan tertentu menurut jenis dan sifat atau kegiatan pekerjaannya akan selesai dalam waktu tertentu seperti:

1. Pekerjaan yang sekali selesai atau sementara sifatnya;

2. Pekerjaan yang diperkirakan penyelesaiannya dalam waktu yang tidak terlalu lama dan paling lama 3 (tiga) tahun;

3. Pekerjaan yang bersifat musiman; atau 
4. Pekerjaan yang berhubungan dengan produk-produk baru, kegiatan baru, atau produk tambahan yang masih dalam percobaan atau penjajakan.

Sementara itu, meskipun PKWT yang dilakukan oleh PT Sentra Info Bisnis Konsultama dengan pekerja tidak mensyaratkan adanya masa percobaan dan jenis pekerjaan PKWT telah sesuai dengan ketentuan Pasal 59 ayat (1) UU Ketenagakerjaan, namun dalam perkara a quo, Majelis Hakim PHI dalam pertimbangannya menilai bahwa PKWT tersebut tetap harus memenuhi ketentuan mengenai jangka waktu PKWT sebagaimana ketentuan Pasal 59 ayat (4),(5), dan (6) yang menyebutkan bahwa PKWT dapat dilakukan untuk jangka waktu paling lama 2 (dua) tahun, kemudian dapat dilakukan perpanjangan 1 (satu) kali untuk jangka waktu paling lama 1 (satu) tahun. Selanjutnya para pihak dapat melakukan pembaharuan PKWT untuk jangka waktu paling lama 2 (dua) tahun.

Pada perkara a quo, Majelis Hakim PHI dalam pertimbangannya menilai bahwa pada awalnnya memang hubungan kerja pekerja dengan PT Sentra Info Bisnis Konsultama didasari pada perjanjian kerja waktu tertentu (PKWT), akan tetapi hubungan kerja tersebut kemudian berlanjut dan sesuai dengan masa kerja pekerja yang diakui oleh PT Sentra Info Bisnis Konsultama.

Keberlanjutan hubungan kerja pekerja tersebut, didasari pada adanya perjanjian bersama (PB) yang dibuat antara pekerja dengan PT Media Komunitas Serpong, yang menyepakati keberlanjutan hubungan kerja pekerja dari PT Media Komunitas Serpong ke PT Sentra Info Bisnis Konsultama dengan jabatan yang sama dengan masa kerja yang tetap terhitung sejak pekerja bekerja di PT Media Komunitas Serpong.
Berlanjutnya hubungan kerja tersebut diperkuat dengan bukti surat himbauan cuti tanggal 27 Mei 2016 yang dikeluarkan oleh PT Sentra Info Bisnis Konsultama yang justru mengakui tanggal masuk kerja pekerja sejak tanggal 3 Agustus 2007. Sehingga masa kerja Penggugat tetap dihitung sejak pekerja bekerja pada PT Media Komunitas Serpong yaitu pada 3 Agustus 2007.

Berdasarkan ketentuan tersebut, oleh karena hubungan kerja tersebut terhitung sejak tanggal 3 Agustus 2007 sampai dengan berakhirnya PKWT tanggal 2 Juli 2016, sehingga total jangka waktu perjanjian kerja yang dijalani pekerja adalah 8 tahun 11 bulan. Berdasarkan ketentuan PKWT, hubungan kerja tersebut seharusnya demi hukum berubah menjadi PKWTT (sebagai pekerja tetap). Hal ini sesuai dengan ketentuan Pasal 59 ayat (7) UU Ketenagakerjaan yang menyebutkan bahwa perjanjian kerja untuk waktu tertentu yang tidak memenuhi ketentuan sebagaimana dimaksud pada ayat (1), ayat (2), ayat (4), ayat (5), dan ayat (6) maka demi hukum menjadi perjanjian kerja waktu tidak tertentu.

Ketentuan mengenai batas waktu PKWT juga dijelaskan dalam Pasal 3 ayat (2) Kepmennakertrans RI No.100/MEN/VI/2004 yang menyebutkan bahwa PKWT sebagaimana dimaksud dalam ayat (1) dibuat untuk paling lama 3 tahun.

Mengenai PHK yang dilakukan oleh pihak perusahaan dan hak-hak pekerja yang timbul akibat dari PHK tersebut, seharusnya tetap mengacu pada ketentuan yang diatur secara rigit dalam UU Ketenagakerjaan dan bukan didasari pada ketentuan perjanjian bersama (PB) sebagaimana terlihat dalam pertimbangan Majelis Hakim MA yang menilai bahwa judex facti tidak mempertimbangkan adanya bukti berupa perjanjian bersama antara pekerja dengan PT Media Komunitas 
Serpong yang menyepakati perjanjian sebelumnya antara pekerja dengan PT Sentra Info Bisnis Konsultama membayar kompensasi Rp.9.000.000,00 (sembilan juta rupiah). Apabila bukti-bukti tersebut dipertimbangkan maka diperoleh fakta hukum telah terjadi Perjanjian bersama dan telah dibayar oleh karenanya sesuai ketentuan Pasal 7 UUPPHI.

Menurut Peneliti, pertimbangan hukum Majelis Hakim MA tersebut keliru dalam melihat para pihak dalam perjanjian bersama (PB). Sebab, dari fakta persidangan diketahui bahwa perjanjian sebelumnya yang dimaksud adalah perjanjian bersama yang dibuat oleh pekerja dengan PT Media Komunitas Serpong, sehingga seharusnya adalah perjanjian bersama (PB) antara pekerja dengan PT Sentra Info Bisnis Konsultama, yang menyepakati PB sebelumnya antara pekerja dengan PT Media Komunitas Serpong, dan bukan antara pekerja dengan PT Sentra Info Bisnis Konsultama.

Sementara itu, dalam hal substansi seharusnya pemberian kompensasi PHK kepada pekerja tidak didasari pada PB sebagaimana pertimbangan Majelis Hakim MA, melainkan harus berpedoman pada ketentuan PHK yang diatur dalam UU Ketenagakerjaan yaitu Pasal 156 ayat (1) yang menyebutkan bahwa dalam hal terjadi pemutusan hubungan kerja (PHK), pengusaha diwajibkan membayar uang pesangon dan atau uang penghargaan masa kerja dan uang penggantian hak yang seharusnya diterima. Sedangkan mengenai besaran jumlah uang pesangon dan/atau uang penghargaan masa kerja dan uang penggantian hak yang diterima oleh pekerja/buruh, seharusnya didasari pada ketentuan yang telah diatur dalam Pasal 156 ayat (2), (3), dan (4).

Berdasarkan ketentuan Pasal 156

ayat (2) UU Ketenagakerjaan, seharusnya hak pekerja atas uang pesangon dengan masa kerja selama 8 tahun 11 bulan adalah sebesar Rp. 62.874.000,00, (enam puluh dua juta delapan ratus tujuh puluh empat ribu rupiah) dan tidak sebesar Rp.9.000.000,00 (sembilan juta rupiah) sebagaimana ketentuan perjanjian bersama $(\mathrm{PB})$.

Disamping itu, dari ketentuan Pasal 156 ayat (1) dan Pasal 156 ayat (2), (3) dan (4), kompensasi PHK yang seharusnya diterima oleh pekerja dari pihak perusahaan terdiri atas uang pesangon, uang penghargaan masa kerja dan uang penggantian hak, yang jumlahnya sebesar Rp.84.355.950,00 (delapan puluh empat juta tiga ratus lima puluh lima ribu sembilan ratus lima puluh rupiah), dan tidak hanya sebatas uang pesangon sebagaimana disepakati pada perjanjian bersama (PB).

Pertimbangan hukum tersebut jelas memperlihatkan bahwa Majelis Hakim MA hanya menjadikan perjanjian bersama (PB) tanggal 3 Juli 2015 sebagai satu-satunya dasar hukum dalam menyelesaikan perkara perselisihan antara pihak perusahaan dengan pekerja dan mengenyampingkan ketentuan pemberian kompensasi PHK yang secara tegas diatur dalam UU Ketenagakerjaan.

Secara hukum perjanjian bersama $(\mathrm{PB})$ yang dijadikan sebagai dasar hukum oleh Majelis Hakim MA seharusnya batal demi hukum (van rechtswegenietig, null and void) karena cacat syarat objektif sebagaimana ketentuan Pasal 1320 KUHPerdata yaitu melanggar syarat kausa atau sebab yang halal karena PB tersebut bertentangan dengan ketentuan UU Ketenagakerjaan, sehingga PB tidak sah dan tidak memiliki kekuatan hukum. 


\section{Kesimpulan}

1. Perjanjian bersama (PB) yang digunakan sebagai dasar hukum oleh majelis Hakim MA dalam menyelesaikan perkara perselisihan antara PT Sentra Info Bisnis Konsultama dan PT Media Komunitas Serpong dengan pekerja seharusnya tidak sah dan tidak memiliki kekuatan hukum. Sebab, secara keabsahan perjanjian bersama yang dibuat oleh para pihak pada tanggal 2 Juli 2015 tidak memenuhi syarat kausa atau sebab yang halal yang tercantum dalam Pasal 1320 KUHPerdata, karena secara substansi bertentangan dengan ketentuan Pasal 156 ayat (1) dan ketentuan Pasal 156 ayat (2), (3), (4) UU Ketenagakerjaan. Sehingga perjanjian bersama (PB) tersebut cacat syarat objektif, yang berakibat PB tersebut batal demi hukum (van rechtswegenietig, null and void), dan tidaklah mempunyai kekuatan hukum sebagaimana ketentuan Pasal 1335 KUHPerdata, termasuk sifat mengikatnya perjanjian bagi para (Pasal 1338 ayat (1) KUHPerdata).

2. Majelis Hakim MA sebagai aplikator UU dinilai tidak cermat dan belum menerapkan UU Ketenagakerjaan secara baik dalam pertimbangan hukumnya. Meskipun hubungan kerja antara PT Sentra Info Bisnis Konsultama dan pekerja didasari pada PKWT, namun dengan adanya keberlanjutan hubungan kerja tersebut, maka hubungan kerja itu berubah menjadi PKWTT sebagaimana ketentuan Pasal 59 ayat (7) UU Ketenagakerjaan, dengan masa kerja yang tetap harus dihitung sejak pekerja bekerja pada PT Media Komunitas Serpong yaitu 3 Agustus 2007 sampai tanggal 2 Juli 2016. Oleh karena itu, dalam hal pemberian kompensasi PHK, Majelis Hakim MA seharusnya memperhatikan lamanya masa kerja pekerja dan tidak didasari pada perjanjian bersama (PB) yang sebelumnya disepakati.

\section{A. Buku-Buku}

\section{DAFTAR PUSTAKA}

Arief Sidharta, dan Mochtar Kusumaatmadja. 2000. Pengantar Ilmu Hukum : Suatu Pengenalan Pertama Ruang Lingkup Berlakunya Ilmu Hukum, Buku I, Bandung: Alumni.

Asikin, Zainal dkk. 2004. Dasar-Dasar Hukum Perburuhan, Jakarta: Rajagrafindo Persada.

Darus Badrulzaman, Mariam. 2015. Hukum Perikatan Dalam KUH Perdata Buku Ketiga (Yurisprudensi, Doktrin, Serta Penjelasan), Bandung: Citra Aditya Bakti.

Husni, Lalu. 2003. Hukum Ketenagakerjaan Indonesia, Edisi Revisi, Cet. Ke-4, Jakarta: Rajagrafindo .2014. Pengantar Hukum Ketenagakerjaan, Edisi Revisi, Jakarta: Rajagrafindo Persada.

H. Manulang, Sedjun. 1995. Pokok-Pokok Hukum Ketenagakerjaan di Indonesia, Jakarta: Rineka Cipta

Khakim, Abdul. 2014. Dasar-Dasar Hukum Ketenagakerjaan Indonesia, Cet. Ke-4 Edisi Revisi, Bandung: Citra Aditya Bakti.

Machmudin, Dudu Duswara. 2010. Pengantar Ilmu Hukum (Sebuah Sketsa), Bandung: Refika Aditama.

Mahkamah Agung RI. 2006.Pedoman Perilaku Hakim (Code Of Conduct), Kode Etik Hakim dan Makalah berkaitan, Jakarta: Pusdiklat MA RI. 
Miru, Ahmadi. 2016. Hukum Kontrak \& Perancangan Kontrak, Jakarta: Rajagrafindo Persada.

Pujiyo, dan Ugo. 2012. Hukum Acara Penyelesaian Perselisihan Hubungan Industrial, (Tata Cara dan Proses Penyelesaian Sengketa Perburuhan), Cet. Ke-2, Jakarta: Sinar Grafika.

Subiandini Gultom, Sri. 2008. Aspek Hukum Hubungan Industrial, Jakarta: Inti Prima Promosindo.

\section{B. Peraturan Perundang-Undangan}

Kitab Undang-Undang Hukum Perdata

Undang-Undang No. 13 Tahun 2003 Tentang Ketenagakerjaan

Undang-Undang No. 2 Tahun 2004 Tentang Penyelesaian perselisihan hubungan industrial

Undang-Undang No. 48 Tahun 2009 Tentang Kekuasaan Kehakiman

Keputusan Menteri Tenaga Kerja dan Transmigrasi Republik Indonesia Nomor KEP.100/MEN/VI/2004 Tentang Ketentuan Pelaksanaan Perjanjian Kerja Waktu Tertentu Menteri Tenaga Kerja dan Transmigrasi Republik Indonesia

\section{Jurnal dan Sumber lainnya}

Charda S., Ujang. "Model Penyelesaian Perselisihan Hubungan Industrial Dalam Hukum Ketenagakerjaan Setelah Lahirnya Undang-Undang Nomor 2 Tahun 2004", Jurnal Wawasan Yuridika, Vol. 1, No. 1, Maret 2017.

https://buruh-online.com/2019/01/ma-dinilai-keliru-persamakan-perjanjian-bersamaseperti-putusan-pengadilan.htm. Diakses pada 5 Desember 2019.

Nuroini, Indi. "Penerapan Perjanjian Bersama Dalam Pemutusan Hubungan Kerja", Jurnal Yudisial, Vol. 8, No. 3, Desember 2015. 